\title{
Pengembangan Media Pembelajaran Aplikasi Tentang Variasi Permainan Bulutangkis untuk Guru KKG PJOK SD Kelas IV
}

\author{
Muhammad Rifqi Mafatikhul Huda*, Ari Wibowo Kurniawan \\ Universitas Negeri Malang, Jl. Semarang No. 5 Malang, Jawa Timur, Indonesia \\ *Penulis korespondensi, Surel: mrifkihuda@gmail.com
}

Paper received: 31-9-2021; revised: 14-9-2021; accepted: 21-9-2021

\begin{abstract}
Learning media is a means used to improve the learning process, the delivery of material content by educators to students by using assistive devices. The purpose of this research is to develop learning media for variations of badminton games for KKG PJOK elementary school teachers for grade IV which is packaged in an attractive way in the form of an articulate storyline application 3 . The method used in this study uses the Lee and Owen research and development model, by following 5 procedures. stages. The results of data analysis showed that 91 percent of media experts, 75 percent of PJOK experts, 75 percent of learning experts, 95 percent of game experts, and 95 percent of badminton experts stated that the product was good. The results of the overall product trial involved 33 KKG teachers with 8 percentages of small group trials ( 81.3 percent) and 25 percentages of large group trials (82.1 percent). Based on these data, it can be concluded that this product is valid and suitable for use by PJOK teachers at SD Sananwetan District, Blitar City.
\end{abstract}

Keywords: development; learning media; badminton

\begin{abstract}
Abstrak
Media pembelajaran merupakan sarana yang digunakan untuk menyempurnakan proses pembelajaran, penyampaian isi materi oleh pendidik kepada peserta didik dengan menggunakan alat bantu. Tujuan dari penelitian ini adalah untuk mengembangkan media pembelajaran variasi permainan bulutangkis untuk guru KKG PJOK SD kelas IV yang dikemas secara menarik dalam bentuk aplikasi articulate storyline 3. Metode yang digunakan dalam penelitian ini menggunakan model pengembangan research and development Lee and Owen, dengan mengikuti 5 prosedur tahapan. Diperoleh hasil analisis data yang menunjukkan 91 persen ahli media, 75 persen ahli PJOK, 75 persen ahli pembelajaran, 95 persen ahli permainan, 95 persen ahli bulutangkis menyatakan bahwa produk baik. Hasil uji coba keseluruhan produk melibatkan 33 guru KKG dengan pembagian uji coba kelompok kecil 8 persentase (81,3 persen) dan uji coba kelompok besar 25 persentase $(82,1$ persen). Berdasarkan data tersebut dapat disimpulkan bahwa produk ini valid dan layak digunakan oleh guru PJOK SD Kecamatan Sananwetan Kota Blitar.
\end{abstract}

Kata kunci: pengembangan; media pembelajaran; badminton

\section{Pendahuluan}

Pendidikan adalah suatu sistem yang dibuat dengan tujuan untuk meningkatkan pengetahuan, sikap, keterampilan dan kemampuan masyarakat suatu bangsa. Menurut Dwiyogo \& Cholifah, (2016) menyatakan bahwa pendidikan terbagi menjadi dua kategori yakni informal dan formal. Pendidikan formal dilaksanakan secara prosedural sesuai ketentuan instansi pendidikan seperti pada sekolah umum, sedangkan pendidikan non-formal adalah pendidikan yang dilaksanakan diluar daripada lembaga pendidikan seperti pelatihan, bimbingan dan sertifikasi. Ketika seseorang menempuh pendidikan maka erat kaitannya dengan pembelajaran, karena syarat untuk bisa dikategorikan sebagai pendidikan apabila didalamnya ada siswa dan guru. 
Pembelajaran merupakan proses dimana terjadinya interaksi (stimulus dan respons) guru yang berada pada satu rumpun belajar untuk membantu pemahaman belajar siswa dengan baik. Pembelajaran berperan penting untuk mencapai keberhasilan tujuan pendidikan. Menurut Tiessen, (2018) menyatakan bahwa pembelajaran adalah rangkaian proses interaksi yang terjadi dimana melibatkan siswa, guru, untuk meningkatkan ilmu pengetahuan, sikap dan keterampilan untuk mencapai tujuan pembelajaran. Pembelajaran harus dikemas secara menarik dengan harapan untuk menambah motivasi minat belajar siswa terhadap mata pelajaran yang ingin disampaikan, dengan menggunakan rumus menarik minat siswa terlebih dahulu ini maka secara otomatis siswa akan terpacu untuk semangat dalam mengikuti pembelajaran. Dalam hal ini guru diharapkan mampu membuat suasana belajar, menarik dan tidak menjenuhkan siswa. Oleh karena itu diperlukan sebuah media pembelajaran agar harapan yang demikian bisa tercapai. Media pembelajaran adalah sebuah sarana alat bantu guru untuk dapat menyampaikan pesan materi sumber belajar dengan menarik. Sejalan dengan pernyataan (Wandah, 2017) menyatakan bahwa media pembelajaran adalah media kreatif perantara dalam menyampaikan materi kepada peserta didik sehingga proses menjadi aktif.

Perkembangan teknologi yang sangat pesat menuntut guru untuk terus meningkatkan kapasitasnya, tidak hanya pengetahuan dan ketrampilan saja melainkan juga adaptasi teknologi masa kini. Penggunaan media seperti handphone dan laptop zaman dahulu tidak begitu banyak yang menggunakan, tapi di masa kini bagi guru yang tidak mampu menggunakan media tersebut akan tertinggal dalam memperoleh informasi secara internasional. Dunia pendidikan juga demikian, telah banyak mengalami banyak perubahan dampak dari era globalisasi saat ini, sudah banyak berkembang media pembelajaran saat ini yang sudah lazim digunakan dalam proses pembelajaran antara lain google meet, google classroom, form, dan zoom. Media-media ini telah berhasil memfasilitasi guru dan siswa untuk bisa belajar secara jarak jauh atau biasa dikenal dalam jaringan (daring). Metode daring sebenarnya sudah aja sejak dulu tahun 1980 di Indonesia, namun pembelajaran daring kian populer baru-baru ini semenjak adanya wabah pandemi Covid-19, pandemi ini telah melanda keseluruh dunia, mengakibatkan WHO membuat keputusan bahwa semua masyarakat dihimbau untuk tidak keluar rumah. Pembelajaran daring memang bisa diimplementasikan untuk mata pelajaran yang sifatnya teori, namun tidak begitu efektif untuk mata pelajaran yang terdapat praktek di dalamnya seperti halnya mata pelajaran pendidikan jasmani kesehatan (PJOK).

Penjaskes merupakan adalah mapel wajib yang diajarkan pada kurikulum sekolah dasar (SD). Mata pelajaran PJOK adalah salah satu contoh yang dalam proses pembelajarannya membutuhkan kombinasi antara teori dan praktek. Mata pelajaran penjas berperan penting untuk membantu pertumbuhan dan perkembangan anak. Pendidikan jasmani adalah proses pembelajaran melalui kombinasi antara aktivitas fisik dan gerak. Pembelajaran pendidikan jasmani yang diajarkan kepada siswa tingkat sekolah dasar terdapat materi bola kecil pada tingkat kelas IV. telah diatur dan disahkan dalam standar kompetensi dasar pada tiap semester. 
Sport Science and Health, 3(9), 2021, 720-729

Tabel 1. KI \& KD Penjaskes Kelas IV

\begin{tabular}{|c|c|}
\hline Kompetensi Inti Kelas IV & Kompetensi Inti Kelas IV \\
\hline $\begin{array}{l}\text { 3. Mampu memahami gerak dasar lokomotor, } \\
\text { non-lokomotor dan manipulatif dalam } \\
\text { permainan bola kecil sederhana. }\end{array}$ & $\begin{array}{l}\text { 4. Mampu memperagakan gerak dasar } \\
\text { lokomotor, non-lokomotor dan manipulatif } \\
\text { dalam permainan bola kecil sederhana. }\end{array}$ \\
\hline Kompetensi Dasar Kelas IV & Kompetensi Dasar Kelas IV \\
\hline $\begin{array}{l}\text { 3.2 Mampu memahami gerak dasar lokomotor, } \\
\text { non-lokomotor, dan manipulatif dalam } \\
\text { permainan bola kecil sederhana. }\end{array}$ & $\begin{array}{l}\text { 4.2 Mampu memperagakan gerak dasar } \\
\text { lokomotor, non-lokomotor, dan manipulatif } \\
\text { dalam permainan bola kecil sederhana. }\end{array}$ \\
\hline
\end{tabular}

Olahraga yang termasuk dalam kategori materi bola kecil diantaranya adalah bulutangkis, tenis meja dan kasti. Namun pada produk pengembangan ini peneliti berfokus untuk mengembangkan pada materi bulutangkis yang dikombinasikan dalam latihan variasi permainan. Bulutangkis termasuk olahraga yang sangat populer di Indonesia, sejak dulu cabor yang banyak menorehkan prestasi untuk Indonesia salah satunya adalah bulutangkis. Bulutangkis adalah olahraga yang bisa dilakukan oleh minimal dua orang dengan berlawanan, dengan hanya membutuhkan raket dan shuttlecock saja permainan olahraga ini sudah bisa dilaksanakan. Sejalan dengan pendapat Subarjah (2011) yang menyatakan bahwa suatu permainan yang dimainkan perorangan berhadapan baik tunggal atau ganda. Bulutangkis dapat dimainkan didalam maupun diluar ruangan. Hal tersebut dapat dijadikan acuan guru untuk meningkatkan keterampilan membuat media pembelajaran sekaligus adaptasi teknologi terhadap perkembangan kemajuan zaman. Menimbang hal yang demikian maka diperlukan sarana untuk memfasilitasi kegiatan guru tersebut dalam menggunakan media pembelajaran sehingga perlu alternatif dikembangkannya alat penunjang pembelajaran melalui aplikasi yang disesuaikan dengan indikator yang ada di sekolah.

\section{Metode}

Dalam penelitian ini digunakan model pengembangan merujuk pada model pengembangan Lee and Owen Lee \& Owen D L., (2004:93) dengan melalui 5 langkah. (1) memperoleh informasi data awal yaitu dengan cara melakukan analisis kebutuhan (need assessment) (2) Desain produk (3) Pengembangan Produk (4) Uji Coba Produk (5) Evaluasi. Data yang diperoleh dalam penelitian pengembangan terbagi menjadi dua yakni kuantitatif dan kualitatif. Data (1) kualitatif didapatkan dari hasil validasi para ahli berupa saran dan masukan, terdapat 5 orang yang ditunjuk sebagai ahli, diantaranya adalah ahli media, ahli PJOK, ahli pembelajaran, ahli permainan dan ahli bulutangkis, Data (2) kuantitatif diperoleh dari hasil uji coba kecil dan uji coba besar berupa persentase. Prosedur ini bertujuan untuk mendapatkan dan mengumpulkan data yang akan digunakan sebagai rujukan untuk menentukan sebuah produk sudah layak digunakan. Terdapat 5 tahapan urutan dalam uji coba produk diantaranya (1) desain uji coba, penyusunan kerangka produk atau storyboard, (2) menentukan subjek uji coba, dimana subjek yang terlibat adalah guru KKG PJOK SD Kecamatan Sananwetan, (3) jenis data, (4) penyusunan instrumen, (5) teknik analisis data. Pada desain uji coba, peneliti akan menggunakan pertimbangan berdasarkan validasi dari para ahli yang berupa saran maupun masukan. Uji coba kelompok kecil melibatkan 8 guru, dan uji coba kelompok besar sejumlah 25 guru. Kemudian dilanjutkan tahap analisis data, yang digunakan adalah statistik deskriptif. Pengumpulan data menggunakan skala likert untuk mengetahui 
tingkat persetujuan seseorang terhadap suatu pernyataan. Terdapat empat pilihan jawaban dengan skor maksimal 4, terbagi rincian sebagai berikut.

Tabel 2. Skala Perhitungan Nilai

\begin{tabular}{lllcc} 
& No. & Keterangan & Jawaban & Skor \\
\hline 1. & Sangat Setuju & A & 4 \\
2. & Setuju & B & 3 \\
3. & Ragu-ragu & C & 2 \\
4. & Tidak Setuju & D & 1 \\
\hline
\end{tabular}

Sumber: Sugiyono (2015)

Dalam menghitung dan mengolah hasil analisis data yang diperlukan, maka digunakan analisa deskriptif kuantitatif persentase menurut Akbar \& Sriwiyana, (2011) berikut:

$$
V=\frac{T S E V}{S-\operatorname{Max}} \times 100 \%
$$

Keterangan:

$\begin{array}{ll}\text { V } & : \text { Validitas Data } \\ \text { TSEV } & \text { : Total skor } \\ \text { Skor max } & \text { : Skor maksimal } \\ 100 \% & \text { : Bilangan konstanta }\end{array}$

Tabel 1. Standar Kualitas Produk

\begin{tabular}{ccl}
\hline Kriteria & Keterangan & \multicolumn{1}{c}{ Makna } \\
\hline $75,01 \%-100,00 \%$ & Sangat Baik & Digunakan tanpa perbaikan \\
$50,01 \%-75,00 \%$ & Cukup Baik & Digunakan dengan revisi kecil \\
$25,01 \%-50,00 \%$ & Tidak Baik & Tidak dapat digunakan \\
$00,00 \%-25,00 \%$ & Tidak Relevan & Terlarang digunakan \\
\hline
\end{tabular}

Sumber: Akbar \& Sriwiyana (2011)

\section{Hasil dan Pembahasan}

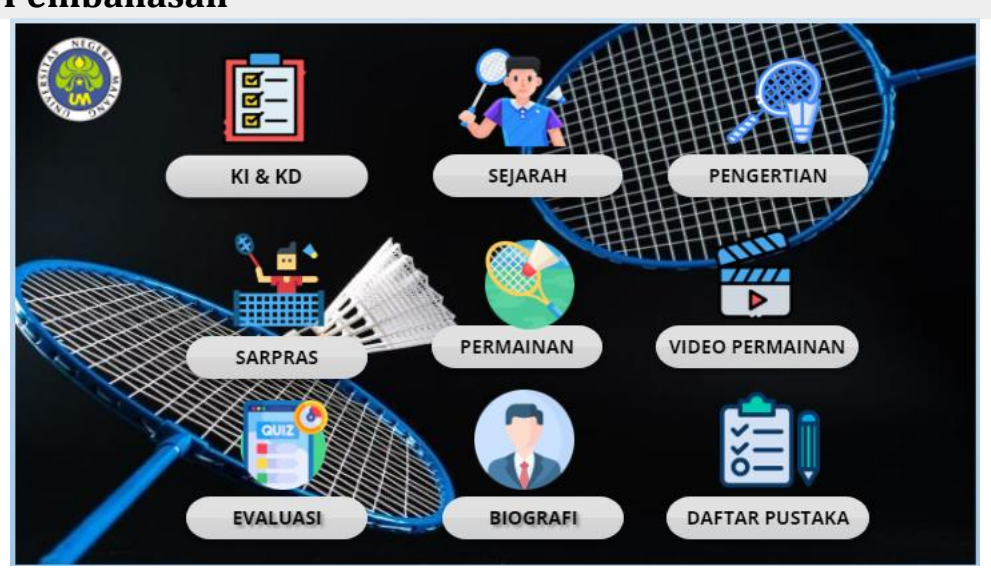

Gambar 1. Tampilan Utama Produk Pengembangan Media Pembelajaran Aplikasi Variasi Permainan Bulutangkis 
Produk pengembangan ini berbasis aplikasi media autoplay yang berisi materi variasi permainan bulutangkis untuk pembelajaran siswa SD kelas IV. Pada aplikasi ini akan memuat kompetensi inti dan kompetensi dasar PJOK kelas IV, sejarah, pengertian, sarana dan prasarana, variasi permainan, kemudian terdapat 5 video permainan untuk kelas IV, evaluasi yang berisi soal-soal untuk kelas IV, serta biodata peneliti.

Data yang diperoleh meliputi data: (1) validasi ahli media, (2) validasi ahli PJOK, (3) validasi ahli pembelajaran, (4) validasi ahli permainan, (5) validasi ahli bulutangkis, (6) uji coba kelompok kecil, dan (7) uji coba kelompok besar

Data yang diperoleh meliputi data: (1) validasi ahli media, (2) validasi ahli PJOK, (3) validasi ahli pembelajaran, (4) validasi ahli permainan, (5) validasi ahli bulutangkis, (6) uji coba kelompok kecil, dan (7) uji coba kelompok besar.

Hasil dapat disajikan dalam bentuk grafik, tabel, atau deskriptif. Pemuatan tabel dan gambar seharusnya hanya berisi informasi esensial hasil riset. Analisis dan interpretasi hasil ini diperlukan sebelum dibahas.

Pembahasan difokuskan pada mengaitkan data dan hasil analisisnya dengan permasalahan atau tujuan penelitian dan konteks teoretis yang lebih luas. Dapat juga pembahasan merupakan jawaban pertanyaan mengapa ditemukan fakta seperti pada data. Pembahasan ditulis melekat dengan data yang dibahas. Pembahasan diusahakan tidak terpisah dengan data yang dibahas.

Tabel 4. Hasil Data Ahli Media

\begin{tabular}{llcll}
\hline No & Aspek & Kriteria & Keterangan & Makna \\
\hline 1. & Kejelasan & 85 & Sangat Valid & Digunakan tanpa perbaikan \\
2. & Ketepatan & 100 & Sangat Valid & Digunakan tanpa perbaikan \\
3. & Kemudahan & 82 & Sangat Valid & Digunakan tanpa perbaikan \\
4. & Kemenarikan & 90 & Sangat Valid & Digunakan tanpa perbaikan \\
5. & Kesesuaian & 80 & Sangat Valid & Digunakan tanpa perbaikan \\
\hline & Rata-rata & 91 & Sangat Valid & Digunakan tanpa perbaikan \\
\hline
\end{tabular}

Berdasarkan hasil analisis data ahli media yang sudah didapatkan menunjukkan presentase sejumlah 91\% dengan kategori sangat valid.

Tabel 5. Hasil Data Ahli PJOK

\begin{tabular}{clcll}
\hline No & \multicolumn{1}{c}{ Aspek } & Kriteria & Keterangan & Makna \\
\hline 1. & Kemudahan & 75 & Sangat Valid & Digunakan tanpa perbaikan \\
2. & Kejelasan & 75 & Sangat Valid & Digunakan tanpa perbaikan \\
3. & Ketepatan & 75 & Sangat Valid & Digunakan tanpa perbaikan \\
4. & Kemenarikan & 75 & Sangat Valid & Digunakan tanpa perbaikan \\
5. & Kesesuaian & 75 & Sangat Valid & Digunakan tanpa perbaikan \\
\hline & Rata-rata & 75 & Sangat Valid & Digunakan tanpa perbaikan \\
\hline
\end{tabular}

Berdasarkan hasil analisis data ahli PJOK yang sudah didapatkan menunjukkan presentase sejumlah $75 \%$ dengan kategori sangat valid. 
Tabel 6. Hasil Data Ahli Pembelajaran

\begin{tabular}{clclc}
\hline No & \multicolumn{1}{c}{ Aspek } & Kriteria & Keterangan & Makna \\
\hline 1. & Kemudahan & 75 & Sangat Valid & Digunakan tanpa perbaikan \\
2. & Kejelasan & 75 & Sangat Valid & Digunakan tanpa perbaikan \\
3. & Ketepatan & 75 & Sangat Valid & Digunakan tanpa perbaikan \\
4. & Kemenarikan & 75 & Sangat Valid & Digunakan tanpa perbaikan \\
5. & Kesesuaian & 75 & Sangat Valid & Digunakan tanpa perbaikan \\
\hline & Rata-rata & 75 & Sangat Valid & Digunakan tanpa perbaikan \\
\hline
\end{tabular}

Berdasarkan hasil analisis data ahli pembelajaran yang sudah didapatkan menunjukkan presentase sejumlah $75 \%$ dengan kategori sangat valid.

Tabel 7. Hasil Data Ahli Permainan

\begin{tabular}{clclc}
\hline No & \multicolumn{1}{c}{ Aspek } & Kriteria & Keterangan & Makna \\
\hline 1. & Kejelasan & 98 & Sangat Valid & Digunakan tanpa perbaikan \\
2. & Ketepatan & 95 & Sangat Valid & Digunakan tanpa perbaikan \\
3. & Kemenarikan & 97 & Sangat Valid & Digunakan tanpa perbaikan \\
4. & Kesesuaian & 90 & Sangat Valid & Digunakan tanpa perbaikan \\
\hline & Rata-rata & 95 & Sangat Valid & Digunakan tanpa perbaikan \\
\hline
\end{tabular}

Berdasarkan hasil analisis data ahli permainan yang sudah didapatkan menunjukkan presentase sejumlah 95\% dengan kategori sangat valid.

Tabel 8. Hasil Data Ahli Bulutangkis

\begin{tabular}{clcll}
\hline No & Aspek & Kriteria & Keterangan & Makna \\
\hline 1. & Kejelasan & 95 & Sangat Valid & Digunakan tanpa perbaikan \\
2. & Ketepatan & 98 & Sangat Valid & Digunakan tanpa perbaikan \\
3. & Kemudahan & 95 & Sangat Valid & Digunakan tanpa perbaikan \\
4. & Kemenarikan & 95 & Sangat Valid & Digunakan tanpa perbaikan \\
5. & Kesesuaian & 95 & Sangat Valid & Digunakan tanpa perbaikan \\
\hline & Rata-rata & 95 & Sangat Valid & Digunakan tanpa perbaikan \\
\hline
\end{tabular}

Dari hasil analisis data ahli bulutangkis yang sudah didapatkan menunjukkan presentase sejumlah 95\% dengan kategori sangat valid.

Tabel 9. Hasil Data Uji Coba Kelompok Kecil

\begin{tabular}{clcll}
\hline No & \multicolumn{1}{c}{ Aspek } & Kriteria & Keterangan & Makna \\
\hline 1. & Kejelasan & 78,1 & Sangat Valid & Digunakan tanpa perbaikan \\
2. & Kemenarikan & 79,3 & Sangat Valid & Digunakan tanpa perbaikan \\
3. & Kemudahan & 92,1 & Sangat Valid & Digunakan tanpa perbaikan \\
4. & Kegunaan & 78,1 & Sangat Valid & Digunakan tanpa perbaikan \\
5. & Kesesuaian & 79,9 & Sangat Valid & Digunakan tanpa perbaikan \\
\hline & Rata-rata & 81,3 & Sangat Valid & Digunakan tanpa perbaikan \\
\hline
\end{tabular}

Dari hasil data setelah dilakukan uji coba kelompok kecil yang sudah didapatkan menunjukkan presentase sejumlah 81,3\% dengan kategori sangat valid. 
Sport Science and Health, 3(9), 2021, 720-729

Tabel 10. Hasil Data Uji Coba Kelompok Besar

\begin{tabular}{clclc}
\hline No & \multicolumn{1}{c}{ Aspek } & Kriteria & Keterangan & Makna \\
\hline 1. & Kejelasan & 86 & Sangat Valid & Digunakan tanpa perbaikan \\
2. & Kemenarikan & 99,6 & Sangat Valid & Digunakan tanpa perbaikan \\
3. & Kemudahan & 82,6 & Sangat Valid & Digunakan tanpa perbaikan \\
4. & Kegunaan & 79 & Sangat Valid & Digunakan tanpa perbaikan \\
5. & Kesesuaian & 96,8 & Sangat Valid & Digunakan tanpa perbaikan \\
\hline & Rata-rata & 82,1 & Sangat Valid & Digunakan tanpa perbaikan \\
\hline
\end{tabular}

Dari temuan data uji coba kelompok besar yang sudah didapatkan menunjukkan persentase sejumlah $82,1 \%$ dengan kategori sangat valid.

Produk penelitian pengembangan ini adalah produk media pembelajaran variasi permainan bulutangkis PJOK SD berbasis aplikasi, yang digunakan yaitu articulate storyline yang didalamnya memuat gabungan beberapa komponen meliputi gambar, teks, audio, video dan grafik. Sejalan dengan pendapat Pratama, (2018) dalam jurnalnya menyatakan bahwa pembelajaran yang diterapkan dengan didukung alat bantu pembelajaran untuk menambah motivasi dan rangsangan keinginan siswa dalam belajar. Menurut (Nugraheni, 2018) menyatakan bahwa articulate storyline adalah sebuah perangkat yang dilengkapi dengan fiturfitur layaknya microsoft power point. Fitur diantaranya adalah picture, movie, music, video, dan lain-lain. Menurut Chotimah (2018), dalam jurnalnya menyatakan bahwa media pembelajaran yang didesain secara menarik dan kreatif memberikan kemudahan pendidik untuk bisa menyampaikan materi yang mudah dipahami peserta didik serta memberikan tambahan motivasi kemampuan minat belajar peserta didik. Pendidikan jasmani adalah salah mata pelajaran yang sangat penting dipelajari oleh peserta didik karena pengetahuan mengenai kesehatan dan olahraga mempunyai peran penting dalam pertumbuhan dan perkembangan peserta didik. Pendidikan jasmani, kesehatan dan olahraga merupakan salah satu mata pelajaran wajib karena termasuk kedalam kurikulum pendidikan (Jatmika, 2014). Dalam mencapai tujuan dari pembelajaran tidak terlepas dari peran seorang guru. Seorang guru yang ahli serta berkompeten di bidangnya akan menghasilkan siswa yang baik pula. Guru pendidikan jasmani adalah tenaga pengajar yang harus selalu mengedepankan skill dan knowledge sesuai kompetensi yang dimiliki yakni melaksanakan tugas dengan kompetensi dan sikap secara profesional (Budiwanto et al., 2012).

Dalam proses pembelajaran kurangnya dukungan dari kompetensi dari guru non-penjas terhadap pembelajaran penjas disebabkan sarana prasarana yang kurang memadai. Proses pembelajaran yang didukung menggunakan alat bantu media pembelajaran memberikan pengaruh yang sangat baik terhadap motivasi dan minat belajar siswa, terjadi interaksi aktif (stimulus-respons) antara pendidik dan peserta didik. Karena bentuk akhir dari produk ini adalah aplikasi yang dapat dioperasikan melalui smartphone, laptop dan web sehingga memberikan kemudahan kepada pengajar serta peserta didik dalam pelaksanaan pembelajaran. Sebagaimana pendapat Janah (2015) yang menyatakan bahwa dalam penelitiannya yang menggunakan aplikasi yang sama yaitu articulate storyline mendapatkan hasil bahwa mobile learning sangat berpengaruh terhadap motivasi belajar siswa sehingga terdapat peningkatan nilai yang didapat siswa, dengan media ini peserta didik lebih bisa belajar secara mandiri dirumah. 
Menurut Mayer, (2020) menyatakan bahwa media pembelajaran dapat dijadikan pesan instruksional multimedia sebagai alat perantara pengiriman pesan yang dikemas melalui gambar dan kata-kata yang terdapat mempersuasi seseorang untuk belajar. Kata-kata yang disampaikan dapat dipaparkan berupa narasi, foto, gambar, infografis, ilustrasi, animasi dan klip video. Singkatnya, desain pesan multimedia dipengaruhi oleh konsepsi seseorang tentang bagaimana pikiran manusia bekerja. Menurut Hayes et al., (2017) yang menyatakan bahwa media pembelajaran adalah sarana pembantu untuk membantu mengajar guru dalam menyampaikan materi. Karena peningkatan sumber daya manusia harus berjalan beriringan dengan peningkatan mutu teknologi untuk menunjang kompetensi para guru dalam mencetak peserta didik yang baik. Semakin maju zaman, penggunaan media pembelajaran wajib untuk dikuasai oleh setiap orang, apalagi bagi pendidik (guru) harus juga dibekali kemampuan untuk mengoperasikan teknologi yang berkembang seiring dengan kemajuan zaman.

Menurut Kurniawan, (2014) menyatakan bahwa olahraga dengan tujuan untuk mencapai prestasi memerlukan pembinaan dan pengembangan secara terstruktur dan berjenjang serta berkelanjutan melalui sarana yang disebut sebagai pertandingan. Untuk itu diperlukan penggunaan bantuan teknologi media audio-visual VCD sebagai suatu sarana ilmu pengetahuan dan teknologi penunjang belajar yang sangat efektif. Alat bantu komunikasi sangat berperan penting dalam mensukseskan keberhasilan belajar siswa, tanpa adanya komunikasi yang baik maka mustahil, siswa akan dapat dengan mudah memahami pelajaran.

Bulutangkis adalah salah satu cabang olahraga populer di Indonesia. Bulutangkis adalah permainan yang dimainkan secara perorangan maupun ganda, olahraga permainan ini dilakukan dengan cara memukul shuttlecock menggunakan raket agar menyeberangi net menuju sasaran atau area lawan (Yuliawan, 2017). Olahraga ini termasuk ke dalam jenis olahraga permainan sehingga menyebabkan banyak masyarakat yang menyukai dan memainkannya.

Produk pengembangan ini dikemas secara menarik dan mudah untuk dioperasikan, juga dengan spesifikasi kapasitas penyimpanan yang ringan. Didalamnya memuat 7 menu bahasan yang merupakan pokok pokok materi pembelajaran PJOK SD diantaranya adalah; $\mathrm{KI} / \mathrm{KD}$, sejarah, pengertian, sarana prasarana, permainan, video permainan, dan evaluasi. Pada menu evaluasi dilengkapi model kuis berbentuk latihan soal multiple choice. Produk ini dapat dijadikan bahan ajar dan diaplikasikan untuk mengajar siswa sekolah dasar mata pelajaran PJOK. Terdapat 5 macam video variasi permainan bulutangkis teknik dasar meliputi gerak lokomotor, nonlokomotor dan manipulatif yang sejalan dengan KI \& KD PJOK SD kelas IV. Produk pengembangan ini dapat membantu guru untuk memberikan pengajaran kepada siswa untuk tujuan memperoleh pengetahuan maupun meningkatkan keterampilan bulutangkis.

Dengan dikembangkannya produk yang didesain melalui media pembelajaran aplikasi ini diharapkan pembelajaran bulutangkis dapat dengan mudah dimengerti oleh siswa, juga guru terfasilitasi dalam menyampaikan materi bulutangkis kepada siswa dalam bentuk permainan.

\section{Simpulan}

Maka dari penelitian pengembangan ini mendapatkan kesimpulan bahwa produk pengembangan media pembelajaran aplikasi variasi permainan bulutangkis yang telah dikembangkan memuat $\mathrm{KI} / \mathrm{KD}$, sejarah, pengertian, sarana prasarana, permainan, video permainan, dan evaluasi dapat layak digunakan dalam pembelajaran PJOK SD kelas IV. 


\section{Daftar Rujukan}

Akbar, S., \& Sriwiyana, H. (2010). Pengembangan Kurikulum dan Pembelajaran Ilmu Pengetahuan (IPS). Cipta Media.

Arwanda, P., Irianto, S., \& Andriani, A. (2020). Pengembangan Media Pembelajaran Articulate Storyline Kurikulum 2013 Berbasis Kompetensi Peserta Didik Abad 21 Tema 7 Kelas Iv Sekolah Dasar. AlMadrasah: Jurnal Pendidikan Madrasah Ibtidaiyah, 4(2), 193. https://doi.org/10.35931/am.v4i2.331

Asnaldi, A. (2017). Persepsi Guru-Guru Non Penjas terhadap Pembelajaran Pendidikan Jasmani Olahraga Kesehatan dan Rekreasi Gugus IV Sungai Jambu Kecamatan Pariangan. Sains Olahraga Dan Pendidikan Jasmani, 10-18.

Budiwanto, S., Winarno, M. E., \& Mardiyanto. (2012). Asesmen Pembelajaran Penjaskes SD. 4

Dwiyogo, W. D., \& Cholifah, P. S. (2016). Continuing Professional Development ( CPD ) for Physical Education Teacher in Elementary School through Blended Learning. International Conference on Education, 14, 948-955.

Hayes, C., Hardian, H., \& Sumekar, T. (2017). Pengaruh Brain Training Terhadap Tingkat Inteligensia Pada Kelompok Usia Dewasa Muda. Diponegoro Medical Journal (Jurnal Kedokteran Diponegoro), 6(2), 402416.

Janah, S. N. (2015). Pengaruh Penggunaan Multimedia Articulate Storyline Dalam Meningkatkan Hasil Pembelajaran Fiqih Di Madrasah Aliyah Negeri 3 Kediri. 151, 10-17

Jatmika, H. M. (2014). Analisis Kelayakan Isi Buku Teks Penjasorkes Kelas X Sma Di Kabupaten Bantul Daerah Istimewa Yogyakarta. Jurnal Pendidikan Jasmani Indonesia, 10(2), 62-67

Kurniawan, A. W. 2014. Pengembangan Pembelajaran Judo Teknik Bantingan Kyu 4 Dengan Media Vcd Untuk Pejudo Pjsi (Persatuan Judo Seluruh Indonesia). Hotel Horison Ultima Jl Green Boulevard, 65125(2), 2537.

Lee, W. W., \& Owen D L. (2004). Multimedia-Based Instructional Design (2nd ed.). Pfeiffer.

Mayer, R. E. (2020). Cognitive Theory of Multimedia Learning. 43-71.

Nugraheni, T. D. (2018). Pengembangan Media Pembelajaran Interaktif Menggunakan Articulate Storyline Pada Mata Pelajaran Sejarah Indonesia Kelas X .... https://lib.unnes.ac.id/32545/

Pamungkas, I. A., \& Dwiyogo, W. D. (2020). Pengembangan Media Pembelajaran Berbasis Mobile Learning Untuk Aktifitas Kesegaran Jasmani Siswa kelas X Sekolah Menengah Kejuruhan. Sport Science and Health, 2(5), 272-278

Purnama, S., \& Asto, B. (2014). Pengembangan Media Pembelajaran Interaktif Menggunakan Software Articulate Storyline Pada Mata Pelajaran Teknik Elektronika Dasar Kelas X TEI 1 Di SMK Negeri 2 Probolinggo. Jurnal Pendidikan Teknik Elektro, 3(2), 275-279. https://doi.org/http://dx.doi.org/10.17977/um003v3i22017p145

Rasang, Firmansyah. (2019). Analisis Gerak Cabang Olahraga Diving. Surabaya : Universitas Negeri Surabaya

Peraturan Pemerintah Nomor 17 Tahun 2010 Tentang Pengelolaan dan Penyelenggarakan Pendidikan. (2010).

Pratama, R. A. (2018). Media Pembelajaran Berbasis Articulate Storyline 2 Pada Materi Menggambar Grafik Fungsi Di SMP Patra Dharma 2 Balikpapan. Jurnal Dimensi, 7(1), 19-35.

Rovi, P. (2016). Penerapan Teori Pembelajaran Kognitif Dalam Pembelajaran Pendidikan Jasmani Dan Kesehatan. Pendidikan Olahraga, 5(2), 154-164.

Rahman, Z., Kurniawan, A. W., \& Heynoek, F. P. (2020). Pengembangan Pembelajaran Kebugaran Jasmani Unsur Kecepatan Berbasis Multimedia Interaktif. Sport Science and Health, 2(1), 78-92

Sainal M. (2018). Buku Ajar Mata Pelajaran Pendidikan Jasmani dan Kesehatan untuk SMA Kelas X Semester I (F. Fabri (ed.)). Uwais Inspirasi Indonesia.

Sapitri, D., \& Bentri, A. (2017). Pengembangan Media Pembelajaran Berbasis Aplikasi Articulate Storyline Pada Mata Pelajaran Ekonomi Kelas X. Seminar Nasional: Jambore Konseling 3,

Setyaningsih, S., Rusijono, \& Wahyudi, A. (2020). Pengaruh Penggunaan Media Pembelajaran Interaktif Berbasis Articulate Storyline Terhadap Motivasi Belajar Dan Hasil Belajar Siswa Pada Materi Kerajaan Hindu. Jurnal Pendidikan dan Ilmu Pengetahuan, 20(2), 144-156 
Subarjah, H., \& Hidayat, Y. (2011). Permainan bulutangkis. Bandung: Bintang

Sugiyono. (2015). Metode Penelitian Pendidikan. Alfabeta.

Sugiyono. (2014). Metode Penelitian Manajemen. Alfabeta

Tiessen, R. (2018). Improving Student Reflection in Experiential Learning Reports in Post-Secondary Institutions. 7(3), 1-10. https://doi.org/10.5539/jel.v7n3p1

Wandah, W. (2017). Desain dan Pemograman Multimedia Pembelajaran Interaktif(D. Fabiharsa (Ed.)). Penerbit Cerdas Ulet Kreatif.

Wati, D. 2017. Pengembangan Media Mobile Learning Dalam Pembelajaran Menulis Deskripsi Pada Siswa Kelas X SMK. Ilmu Budaya, 1(May), 291-304. https://media.neliti.com/media/publications/240569pengembangan-media-mobile-learning-dalam-2d6956eb.pdf

Yuliawan, D. (2017). Bulu Tangkis Dasar (1st ed.). CV Budi Utama.

Yumini, Si., \& Rakhmawati, L. 2015. Pengembangan Media Pembelajaran Interaktif Berbasis Articulate Storyline Pada Mata Diklat Teknik Elektronika Dasar Di Smk Negeri 1 Jetis Mojokerto. Jurnal Pendidikan Teknik Elektro, 4(3), 845-849 